\title{
The challenge of tobacco control at a university hospital
}

O desafio de controlar o tabagismo em um hospital universitário

El reto de la lucha contra el tabaco en un hospital universitario

GE Revista Gaúcha de Enfermagem

\author{
Natália Ferreira Cruz ${ }^{\mathrm{a}}$ \\ Vanessa Monteiro Mantovani ${ }^{\text {b }}$ \\ Sérgio Von Poser Macielc \\ Solange Klockner Boaz ${ }^{c}$ \\ Marli Maria Knorst ${ }^{d}$ \\ Isabel Cristina Echer ${ }^{\mathrm{e}}$
}

DOl: $\quad$ http://dx.doi.org/10.1590/19831447.2015.03.52432

\footnotetext{
anidade de Pronto Atendimento Niteroi. Porto Alegre, Rio Grande do Sul, Brasil.

b Universidade Federal do Rio Grande do Sul (UFRGS) Escola de Enfermagem. Porto Alegre, Rio Grande do Sul, Brasil.

' Hospital de Clínicas de Porto Alegre (HCPA). Porto Alegre, Rio Grande do Sul, Brasil.

${ }^{d}$ Universidade Federal do Rio Grande do Sul (UFRGS). Faculdade de Medicina. Porto Alegre, Rio Grande do Sul, Brasil.

e Universidade Federal do Rio Grande do Sul (UFRGS). Escola de Enfermagem. Porto Alegre, Rio Grande do Sul, Brasil. Hospital de Clínicas de Porto Alegre (HCPA) Porto Alegre, Rio Grande do Sul, Brasil.
}

\section{ABSTRACT}

Objective: To identify the actions taken by the Commission of Tobacco Control (CTC) to control smoking in the hospital environment. Methods: Descriptive and exploratory retrospective documentary research conducted at a university hospital in southern Brazil, in 2014. The content of the minutes of CTC meetings was used to create a database, and the rounds reports were descriptively analyzed. We sought to identify the most relevant actions from 2005 to 2014.

Results: The CTC implemented the Tobacco-Free Environment programme restricted cigarette smoking to designated areas and subsequently deactivated these areas. The only remaining outdoor smoking area in 2014 was deactivated.

Conclusion: CTC actions have contributed to tobacco control in the hospital environment. This study will hopefully serve as a model to encourage other institutions to implement similar actions.

Keywords: Tobacco control campaigns. Tobacco smoke pollution. Smoking areas.

\section{RESUMO}

Objetivo: Identificar as ações desenvolvidas por uma Comissão de Controle do Tabagismo (CСT) para controlar o fumo do ambiente hospitalar.

Métodos: Pesquisa documental descritivo-exploratória retrospectiva, realizada em hospital universitário do sul do Brasil, em 2014. Construiu-se um banco de dados com o conteúdo das atas de reuniões da CCT e relatório das rondas realizadas, o qual foi analisado de forma descritiva. Buscou-se identificar as ações mais relevantes no período de 2005 a 2014.

Resultados: A CCT implementou o Programa Ambiente Livre do Tabaco, restringiu o consumo do cigarro aos fumódromos e posteriormente desativou os mesmos. Permaneceu somente uma área externa de tolerância ao fumo até 2014 , a qual foi desativada.

Conclusões: As ações da CCT contribuíram para controlar o fumo do ambiente hospitalar. Espera-se que este estudo sirva de incentivo e modelo para outras instituições.

Palavras-chave: Campanhas para o controle do tabagismo. Poluição por fumaça de tabaco. Áreas destinadas ao tabagismo.

\section{RESUMEN}

Objetivo: Identificar las medidas adoptadas por la Comisión de Control del Tabaco (CCT) para controlar el tabaquismo del entorno hospitalario.

Métodos: Investigación documental retrospectiva descriptiva y exploratoria, realizada en hospital universitario en el sur de Brasil, en 2014. Construyó una base de datos con el contenido de las actas de las reuniones del CCT y la notificación de las rondas realizadas, que se analizó descriptivamente. Se buscó identificar las acciones más relevantes, en el periodo 2005-2014.

Resultados: El CCT implementó el Programa de Ambiente Libre de Tabaco, restringió el consumo de cigarrillos a las instalaciones designadas, y luego los convirtió. Sólo quedaba un área externa de la tolerancia al consumo de tabaco en 2014, que fue desactivado. Conclusiones: Las acciones del CCT ayudaron a controlar el tabaquismo del hospital. Se espera que este estudio sirva de estímulo y modelo para otras instituciones.

Palabras clave: Campañas para el control del tabaquismo. Contaminación por humo de tabaco. Áreas destinadas a fumadores. 


\section{DINTRODUCTION}

Smoking is responsible for five million deaths in the world each year, and 200 of these deaths occurred in Brazil. It is considered a risk factor for about 50 diseases, especially cancer, acute myocardial infarction, stroke and respiratory diseases. In addition, passive smoking is considered the third cause of preventable death in the world. The effects of passive smoking on the cardiovascular system are equivalent to the risks incurred by people who smoke one to nine cigarettes a day ${ }^{(1)}$.

In Brazil, law 9294/96 allowed smoking in smoking areas, that is, areas solely intended for smoking that should be isolated and well-ventilated, which did not always occur and consequently posed a health hazard to others ${ }^{(1)}$. Globally, this scenario changed in 2005 when the Framework Convention on Tobacco Control came into force. This treaty recommended that countries adopt measures to protect their population from the risks of passive smoking in public places, at work and in public transportation (2).

In 2011, law 12,546 prohibited smoking in closed collective public or private locations all over Brazil|(3). Subsequently, a study conducted in bars of Sao Paulo showed that the concentration of nicotine in the air had dropped $72 \%$, which means better air quality and a reduction in the risks of passive smoking ${ }^{(4)}$.

Within hospital environments, smoking is strictly forbidden because these institutions evidently aim to promote and restore health and prevent health issues ${ }^{(5)}$. However, two Brazilian studies carried out at a university hospital showed that smoking is still prevalent among employees, which indicates the need to create a specific tobacco control programme for this population in order to improve health and quality of life and prevent tobacco-related diseases ${ }^{(5-6)}$.

Although health professionals are aware of the hazards of smoking, they have difficulty in approaching and evaluating smokers. A study showed that nurses of an inpatient unit focused on identifying the smoking status and its association with the underlying disease of patients, but little is done to advise and support the hospitalized smokers ${ }^{(7)}$. Another study identified similar results and suggested the creation of an institutional programme to train professionals that have intense contact with patients, considering that during hospitalization concerns with the current health state increase the motivation to stop smoking ${ }^{(8)}$.

Consequently, the Commission of Tobacco Control (CCT) of the Hospital de Clínicas de Porto Alegre (HCPA), established in 1989, addresses health promotion actions for the people who circulate in the facilities of the institution, and defines strategies to control tobacco use. This commission is formed by professionals in the fields of medicine, nursing, social services, safety, surveillance, engineering and people management.

The relevance of the topic of smoking, the importance of tobacco control and the scarcity of studies that describe smoking restriction actions in Brazilian and international hospitals prompted this study. An analysis of the actions of the CCT can improve planning and the qualification of its future activities. Moreover, the results of this analysis can serve as encouragement and as a model for other institutions.

The guiding question for research was: what actions have been carried out by the Commission of Tobacco Control to make the HCPA a tobacco-free environment? To answer that question, this study was conducted with the aim of identifying the activities of the CCT to control smoking in the hospital environment.

\section{口 METHOD}

This study is based on descriptive-exploratory retrospective documentary research that enables the observation of the maturation or evolution process of individuals or groups, and creates new ways to understand the facts and know how these facts occurred(9).

This study was conducted in the HCPA, a large teaching hospital that is a benchmark in the fields of health education, care and research. This hospital also offers services in more than 60 specialties, mostly for the Unified Health System (SUS). In 2013, there were 32,114 hospital admissions and 600,493 consultations at the hospital with a staff of 6,202 professionals. In 2005, there were 27,033 hospital admissions and 538,520 consultations at the hospital, and a staff of 3,983 employees. These data demonstrate the high number of workers and users who attended the hospital during the study period.

The CCT was created to control tobacco use and consequently improve the quality of life, health, comfort and safety of patients, visitors, employees, teachers, residents, students, researchers, and others. The commission meets every month to discuss and define actions for tobacco control and to promote the health of the community that circulates within the institution. It is also responsible for maintaining anti-smoking promotion, education and training activities for the care teams, and for providing assistance to smokers who want to quit.

The CTT documents include the minutes of the meetings and the rounds reports. After the meetings, the minutes were summarized according to the institution's model and printed and/or scanned. The data related to the 
commission's tobacco control initiatives at the institution were investigated for this study.

The rounds reports are arranged in Microsoft Excel spreadsheets and contain information on the number of smokers found in the visited areas, their link with the hospital, and the amount of cigarette butts found. These three variables were included in the study.

The rounds are completed in indoor and outdoor areas of the hospital by a nursing scholarship student and a guard, with the support of the professional cleaning staff. In 2012, the rounds initially occurred twice a week, followed by three times a week in 2013 to improve surveillance.

The purpose of the rounds is to approach/guide people who are smoking in inappropriate places. When an individual is caught smoking, the intervention consists of warning the individual of the smoking prohibition and providing guidelines on how to stop smoking. Since 2014, any health worker caught smoking received these guidelines, a verbal notification and, subsequently, a written notification. This notification is forwarded to the immediate superior for the appropriate action.

Data were collected from these documents from January and October 2014. The analyzed documents comprised the meeting minutes from January 2005 to October 2014 and the rounds reports starting November 2012, which is when they were implemented. Before this period, the CTT did not offer this strategy.

The meeting minutes were analyzed with the members of the CCT, who, in light of this activity, defined the criteria for listing the main initiatives of the commission for each year. The researchers focused on the activities that effectively helped reduce the number of smokers in the hospital perimeter, according to the members of the commission. The rounds reports were analyzed using descriptive statistics, resulting in an absolute and relative frequency of the variables.

Ethical aspects were observed as specified in Resolution 466/2012 of the Conselho Nacional de Saúde. The project was approved in 2014 by Comitê de Ética em Pesquisa of the Hospital de Clínicas de Porto Alegre, under number 14-0122. The researchers signed a statement of commitment to use the data.

\section{—RESULTS}

During the analyzed period, the CCT engaged in several activities to control smoking at the institution, as shown in Chart 1.

Chart 1 shows the permanent awareness, education and team training activities of the CCT that target smoking cessation and meeting the needs of smokers with support groups, medication and treatment, and the restrictive activities to control smoking in the hospital perimeter.

It is important to note that two smoking areas were deactivated in 2011 to reduce passive smoking. The areas were deactivated before the law was published, by decision of the CCT with the support of the internal community, chiefly because these areas were in the transit areas.

The rounds were initiated with the inspection of 24 locations twice a week. Some of these locations were partially hidden, which facilitated smoking. The number of inspected locations was subsequently increased to ensure greater control of the area.

Figure 1 shows the number of cigarette butts found on the floor during the 208 days of inspection in 28 areas of the hospital, indicating that people are still smoking in these places although they were not found at the time of inspection. Even with the non-smoking signs, rounds reports showed that, when approached, smokers claim they can smoke because there are cigarette butts on the floor.

In 2006 and 2007, cigarette butts were randomly counted at four locations for two days as an awareness strategy for the professionals. However, this activity was only officially implemented in 2012 during the rounds that were completed twice a week. In2013, the frequency was increased to three times a week. The number of available bins remained the same, indicating that they did not influence the result.

The number of smokers in the hospital environment increased in the third period $-11 / 2013$ to $04 / 2014$, when 448 (36.5\%) smokers were found. In the last semester, the number of smokers dropped to 400 (32.6\%). The period between 05/2013 and 10/2013 had the lowest number of smokers, 143 (11.7\%) (Figure 2).

In the studied period, 1,227 smokers were registered in the rounds reports. Of these 1,227 smokers, 254 (20.7\%) were family members, 75 (6.1\%) were employees, 47 (3.8\%) were patients, 34 (2.8\%) were outsourced workers, and 817 (66.6\%) were smokers without an identifiable link to the hospital (Table 1).

Table 1 demonstrates that the notifications helped reduce the number of employees found smoking. The notifications are applied whenever a guard finds an employee smoking in an inappropriate location. The CCT documents show that over the past few years the institutions has been investing in training for the hospital guards in order to prepare them to approach and notify people who smoke in inappropriate places.

It should be noted that, invariably, all the people who are found smoking, whether staff, patients or visitors, are 


\begin{tabular}{|c|c|}
\hline Year & Key initiatives of the cct \\
\hline 2005 & $\begin{array}{l}\text { - Creation of the Tobacco-Free Environment programme (PALT). } \\
\text { - Preparation of a folder with guidelines on the risks of smoking and the benefits of quitting. } \\
\text { - Recreational activity that describes diseases related to smoking and offers awards. } \\
\text { - Definition of appropriate locations for setting up smoking areas. } \\
\text { - Signalling locations where smoking is prohibited. } \\
\text { - Educational activities for the parents of hospitalized children. } \\
\text { - Training of inspection and cleaning teams, with the identification of critical smoking spots. } \\
\text { - Review of the CCT statute. } \\
\text { - Start of multidisciplinary anti-smoking outpatient assistance for patients and hospital staff. } \\
\text { - Partnership with the pharmacy in order to store and distribute specific drugs for the withdrawal } \\
\text { symptoms. }\end{array}$ \\
\hline 2006 & $\begin{array}{l}\text { - Launch of the PALT, with the encouragement of discussions on smoking, the reduction of passive } \\
\text { smoking in the hospital area and the provision of treatment for staff and patients. } \\
\text { - Theatre plays in the outpatient units and corridors, distribution of brochures and information on the } \\
\text { risks of smoking. } \\
\text { - New non-smoking signs on the premises of the HCPA. } \\
\text { - Cigarette butt counting: in two days, 1,820 butts were found in four non-smoking areas. } \\
\text { - Creation of four smoking rooms for the staff of the HCPA and one for outpatients and their families. } \\
\text { - The First Jornada sobre Tabagismo (Non-Smoking Day) at the HCPA, with training for outreach } \\
\text { multipliers for the PALT. }\end{array}$ \\
\hline 2007 & $\begin{array}{l}\text { - Cigarette butt counting: in two days, 3,300 cigarette butts were found in four inappropriate locations, } \\
\text { which is } 81 \% \text { higher than the previous count. } \\
\text { - Graduation of the worker team trained through the PALT. } \\
\text { - Creation of a new awareness campaign to increase the use of smoking areas. } \\
\text { - Training for "PALT multipliers" in partnership with the Projeto Fumo Zero. Subject: risks of environmental } \\
\text { exposure to tobacco smoke. } \\
\text { - Presentation of PALT actions with reports of employees and users who managed to quit smoking, and } \\
\text { an exhibition with panels on the subject. } \\
\text { - Walk around the hospital with the distribution of pamphlets and guidelines to smokers. }\end{array}$ \\
\hline 2008 & $\begin{array}{l}\text { - Reinforcement of signs in the non-smoking areas. } \\
\text { - Notification to inpatients on the smoking prohibition at the HCPA. } \\
\text { - Expansion of outpatient assistance and groups for smokers. } \\
\text { - Review and approval of the CCT statute. } \\
\text { - Competition "How I quit smoking" with prizes for the participants with the best statements on how } \\
\text { they quit smoking. } \\
\text { - Training on smoking for guards, receptionists and lift operators. } \\
\text { - Awareness campaign on smoking, recreational activity and } \\
\text { distribution of folders on the non-smoking policy and use of smoking areas. }\end{array}$ \\
\hline 2009 & $\begin{array}{l}\text { - Update of the folder containing guidelines on the risks of smoking and the benefits of quitting. } \\
\text { - Recreational activities on the dangers of smoking and the benefits of quitting. }\end{array}$ \\
\hline 2010 & $\begin{array}{l}\text { - Creation of the handbook on smoking with tips on how to quit. } \\
\text { - Review of the folder with guidelines on the risks of smoking and tips on how to quit. }\end{array}$ \\
\hline
\end{tabular}

Chart 1 - Main initiatives of the Commission of Tobacco Control in the area of HCPA. Porto Alegre (RS), Brazil, 2014 (continue) 


\begin{tabular}{|c|c|}
\hline 2011 & $\begin{array}{l}\text { - Deactivation of two smoking rooms in the transit area. } \\
\text { - Training of surveillance staff to control tobacco use at the HCPA. }\end{array}$ \\
\hline 2012 & $\begin{array}{l}\text { - Standardization of the Tobacco Control Policy and Plan to ensure compliance with the model proposed } \\
\text { by the Joint Commission International. } \\
\text { - Closing of other smoking rooms in the hospital zone. } \\
\text { - Beginning of the rounds, twice a week. } \\
\text { - Beginning of smoking cessation groups for employees who smoke. } \\
\text { - Temporary booth to divulge the treatment available to workers of the HCPA, with the distribution of } \\
\text { brochures and tips on smoking cessation. } \\
\text { - Promotion of an event on smoking, with tips on how to approach the smoker and the smoking } \\
\text { situation in Rio Grande do Sul. }\end{array}$ \\
\hline 2013 & $\begin{array}{l}\text { - Expansion of the number of rounds to three times a week. } \\
\text { - Display of panels with messages and testimonials of workers who managed to quit smoking. } \\
\text { - Message inserted in the employee paycheck: "29/8, National } \\
\text { Anti-Smoking Day: living well is living without cigarettes". } \\
\text { - Training for guards on how to control smoking on the premises of the HCPA. } \\
\text { - Preparation and distribution of folder containing the tobacco control policy and guidelines related to } \\
\text { cessation. } \\
\text { - Announcement on the start of notifications for workers found smoking in a non-smoking zone, in } \\
2014 \text {. }\end{array}$ \\
\hline 2014 & $\begin{array}{l}\text {-Start of verbal notifications (first event) and written notifications (second event) to employees caught } \\
\text { smoking in inappropriate places (January). } \\
\text { - New "No Smoking" signs (March). } \\
\text { - Start of written notice from the first event (May). } \\
\text { - Stand to assist the external and internal public on smoking cessation and treatment available to } \\
\text { employees. } \\
\text { - Deactivation of the smoking tolerance zone in the perimeter of the HCPA (August). }\end{array}$ \\
\hline
\end{tabular}

Chart 1 - Main initiatives of the Commission of Tobacco Control in the area of HCPA. Porto Alegre (RS), Brazil, 2014 (conclusion) Source: Research data, 2014.

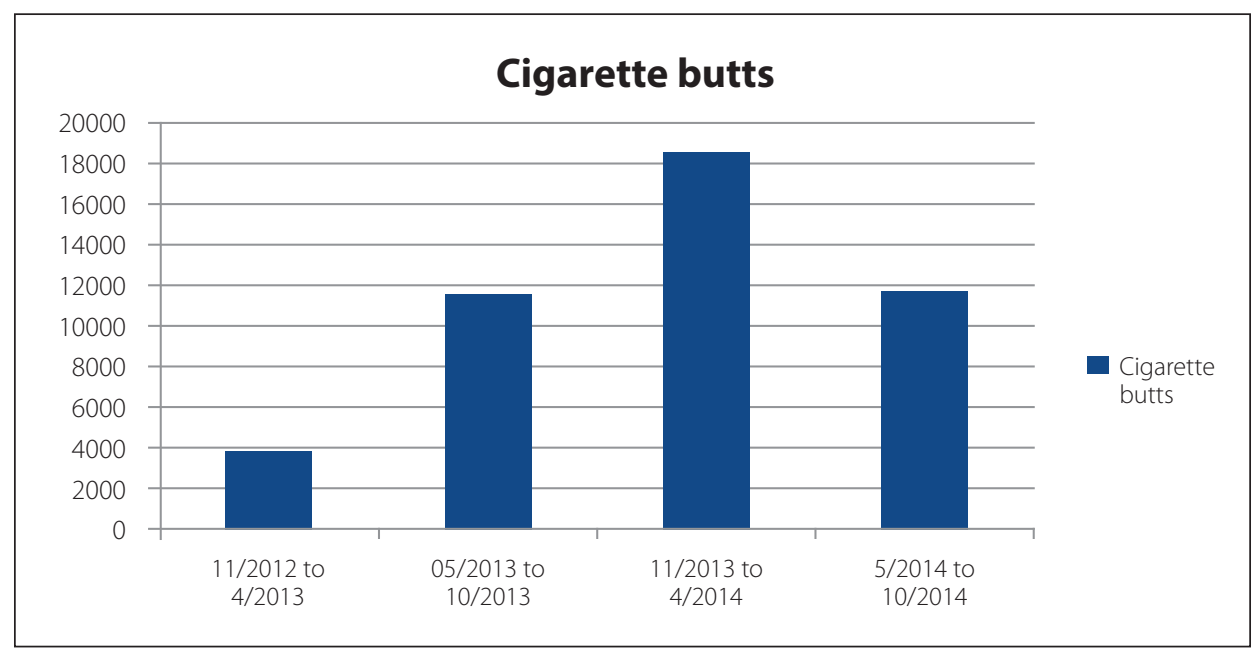

Figure 1 - Number of cigarette butts found during the 208 days of inspection in the 28 locations of the HCPA between November 2012 to October 2014. Porto Alegre (RS), Brazil, 2014

Source: Research data, 2014. 


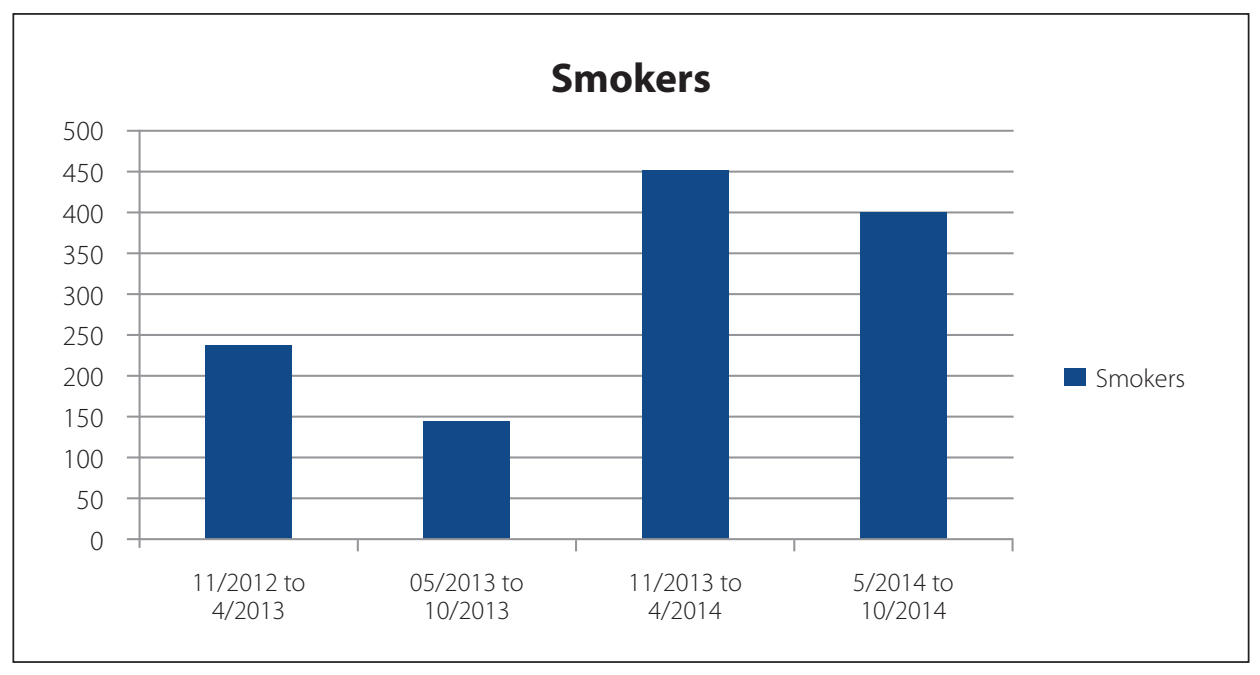

Figure 2 - Number of smokers found in 208 days of inspection carried out in 28 spots of the HCPA. Porto Alegre, November 2012 to October 2014. Porto Alegre (RS), Brazil, 2014

Source: Research data, 2014.

Table 1 - Frequency and percentage of individuals linked to the hospital found smoking in the perimeter of the HCPA. Porto Alegre (RS), Brazil, 2014

\begin{tabular}{lcccccc}
\multicolumn{1}{c}{ Period } & $\begin{array}{c}\text { Employee } \\
\text { N (\%) }\end{array}$ & $\begin{array}{c}\text { Patient } \\
\mathbf{N}(\%)\end{array}$ & $\begin{array}{c}\text { Family } \\
\text { Member } \\
\mathbf{N}(\%)\end{array}$ & $\begin{array}{c}\text { Outsourced } \\
\text { worker } \\
\mathbf{N}(\%)\end{array}$ & $\begin{array}{c}\text { Not identified } \\
\mathbf{N}(\%)\end{array}$ & $\begin{array}{c}\text { Total per } \\
\text { period } \\
\mathbf{N}(\%)\end{array}$ \\
\hline $\mathbf{1 1 / 2 0 1 2 - 4 / 2 0 1 3}$ & $21(8.9)$ & $18(7.6)$ & $185(78.4)$ & $12(5.1)$ & 0 & $236(19.2)$ \\
$\mathbf{5 / 2 0 1 3 - 1 0 / 2 0 1 3}$ & $29(20.2)$ & $14(9.8)$ & $48(33.6)$ & $4(2.8)$ & $48(33.6)$ & $143(11.7)$ \\
$\mathbf{1 1 / 2 0 1 3 - 4 / 2 0 1 4}$ & $21(4.8)$ & $13(2.9)$ & $18(4.0)$ & $18(4.0)$ & $378(84.3)$ & $448(36.5)$ \\
$\mathbf{5 / 2 0 1 4 - 1 0 / 2 0 1 4}$ & $4(1)$ & $2(0.5)$ & $3(0.75)$ & 0 & $391(97.75)$ & $400(32.6)$ \\
\hline Total per link & $75(6.1)$ & $47(3.8)$ & $254(20.7)$ & $34(2.8)$ & $817(66.6)$ & $1227(100)$ \\
\hline
\end{tabular}

Source: Research data, 2014.

notified of the tobacco control policy of the institution and the need to stop smoking immediately in the perimeter of the HCPA. They are also advised on how to seek help to quit smoking.

\section{DISCUSSION}

This study showed that the CCT is active in the institution. Over the years, it has promoted different activities to encourage smokers to quit and restrict consumption, and it has increased access to effective cessation methods and reduced the risks of active and passive smoking.

Most of these actions were carried out on holidays, such as May 31, the World No Tobacco Day, established in 1988 by the World Health Assembly, and August 29, the National Anti-Smoking Day, created in June 1986 $6^{(1)}$. Over the years, the CCT has promoted activities on those dates to emphasize the dangers of smoking and the consequences of passive smoking, especially in relation to maintaining a smoke-free environment and divulging possible treatments for people who want to quit smoking.

The Plano para Implantação da Abordagem e Tratamento do Tabagismo, a tobacco approach and treatment plan, of the SUS, and the Protocolo Clínico e Diretrizes Terapêuticas-Dependência à Nicotina, or clinical protocol and therapeutic guidelines for smokers, were approved in 2004(10). To comply with the requirements of the Ministry of Health, the CCT created the Tobacco-Free Environment (PALT) programme in 2005.

The PALT was launched in 2006 with the creation of smoking areas and the restriction of tobacco consumption in other parts of the institution. These actions were part of 
the initiative for the hospital to become a benchmark for the treatment of smokers by the Ministry of Health and by the INCA, which coordinate the tobacco programme at a national level(10).

One of the main goals of the PALT is to reduce the environmental pollution caused by smoking, which is associated with serious illnesses. It aims to create 100\% tobacco-free environments to protect workers and the public from the harmful effects of cigarette smoke ${ }^{(11)}$. On average, the smoke-polluted air contains three times more nicotine and carbon monoxide and up to fifty times more carcinogenic substances than the smoke that comes from the mouth of smokers ${ }^{(12)}$.

In 2011, after the ban on smoking in enclosed public or private collective establishments across the country ${ }^{(3)}$, the smoking areas in the HCPA were deactivated. In this period, the CCT created the rounds in order to guide and monitor compliance with this law in the indoor and outdoor areas where smoking was prohibited.

Consequently, the importance of training the doormen and surveillance staff to clearly, gently and firmly provide information to employees, patients and visitors of the smoking restrictions in the hospital environment has already been described in the study carried out in São Paulo ${ }^{(13)}$. At the HCPA, the CCT trained the reception, surveillance and cleaning staff on how to approach smokers and notify them of the rules of the institution.

The same study ${ }^{(13)}$ also suggests that hospitals access areas must contain warnings about the smoking restrictions. The HCPA has non-smoking signs inside and outside the institution. These signs are replaced when necessary and additional signs are placed in locations where the restriction is being ignored. Although the signs exist, the rules are clear and smokers are aware of the ban, some cannot resist the urge to smoke and violate the rules, compromising their health and the health of others.

A recent study related to the prohibition of smoking in a hospital of Egypt identified some difficulties in implementing the ban, such as overly tolerant tobacco control laws, lack of penalties for violators and a shortage of cessation programmes ${ }^{(14)}$. In this context, the HCPA offers smoking cessation support to patients and staff and currently bans tobacco use.

However, the verbal notifications were only established in 2012, and the written notifications were established in May 2014. One of the difficulties perceived by the CCT is that the hospital guards feel uncomfortable when approaching smokers, who are often co-workers. Another obstacle is the low number of guards in the night shift, which limits surveillance during this period. Furthermore, until
August 2014, the institution provided an external location for smoking that was close to the non-smoking locations, thus hindering effective surveillance.

In addition to banning cigarette consumption in the workplace, the institution is concerned with the health of hospital workers and provides support for smokers who wish to quit. In the periodic review of the HCPA, the workers who smoke are warned of the risks of smoking. A study shows that the periodic review is an excellent opportunity to identify, advise and motivate workers who smoke to seek treatment for their addiction in order to prevent diseases and promote health within the company ${ }^{(15)}$. Another study reports that employees need guidance and encouragement to help them decide to quit and overcome their smoking habit ${ }^{(16)}$.

A comparison between the number of cigarette butts found in 2007 with the current data revealed a significant reduction. One of the adopted strategies was the partnership with cleaning services, since, as found in the rounds reports, some of the smokers who were approached justified their action by claiming that there were cigarette butts on the floor.

The data analyzed during the rounds show that the number of people found smoking has increased in the last year, even with the active work of the CCT. It is important to point out that when a person is found smoking, they are warned about the smoking ban and asked to extinguish their cigarette or asked to leave the hospital perimeter.

Although the number of people found smoking in the inspected areas has increased, smokers are no longer found inside the institution, but rather in the open adjacent access areas. This increase could be partly due to the intensity of surveillance and inspection activities inside the hospital. The steady growth of staff members and consultations in the hospital may also explain this finding, since there are now more people circulating inside the hospital.

The number of employees caught smoking decreased after the implementation of notifications. This may show that the change in smoking behaviour occurs mostly after the implementation of more severe restrictions. According to a study, smoking is still a major public health problem that requires attention and constant surveillance regarding social control policies in order to change this behaviour ${ }^{(17)}$. It should also be noted that this legislation is recent and that these cultural changes require time to occur.

The reduced number of smokers who are employed at the institution also suggests that the surveillance and notification of offenders have been efficient mechanisms to reduce tobacco use in the institution and need to continue together with educational measures. Despite the evident 
difficulties, many indicators suggest that there have been advancements. An additional strategy would be to fine smokers who throw butts on the floor, which also complies with the current legislation ${ }^{(18)}$.

The period between May and October 2013 had the lowest number of smokers. Specifically in this period, the rounds were completed in the afternoon and in the morning. In the afternoon, the number of smokers was lower because they had already been notified in the morning.

When being admitted to hospital, patients and their families receive a booklet with their rights and duties, which includes the smoking restriction. A study showed that hospitalized patients who smoke are motivated and willing to quit smoking because the smoking restrictions in the hospital environment, their health issues and the hospitalization itself force them to think about their smoking habit. However, the results of this study showed that, in the clinical practice, smoking cessation does not occur as expected because hospitalized smokers are not systematically approached ${ }^{(19)}$.

The support of family members and loved ones reinforces the smokers' decision to quit and should therefore be included in the orientation process ${ }^{(20)}$. The HCPA receives daily a large number of people who need to be notified of the restriction during the rounds despite the current legislation and the non-smoking signs.

Support for smokers and the provision of cessation services are important measures for a health institution to become $100 \%$ smoke-free ${ }^{(14)}$. The main objective of smoking cessation support actions is to motivate smokers to quit smoking and increase access to effective treatment methods for tobacco addiction ${ }^{(20)}$. In this sense, the HCPA offers smoking cessation support to workers and patients. Moreover, when patients are discharged from hospital, they are encouraged to seek outpatient assistance for smokers and the services provided by the basic health system. The waiting period for this service is still long, reaching almost four months, which can be discouraging and should therefore be improved.

This scenario shows that tobacco control is important and does not merely depend on the individual, but on the articulation of different strategies and sectors of society, as well as efficient public policies.

\section{- CONCLUSIONS}

The results show the concern of the HCPA with tobacco control, since several educational, restrictive and punitive activities were created to control tobacco use in the institution. These actions include the PALT, the smoking restric- tion to specific smoking areas and the subsequent deactivation of these areas, and the notifications to employees. Other actions include professional support for patients and employees of the institution.

The limitations of this study are related to the retrospective design of research based on pre-existing databases that implies the possibility of partial or absent records.

It is believed that this study can contribute to the implementation of new measures and serve as encouragement and as a model for other health institutions. Nurses play an important role in health education and care, and must promote educational and preventive interventions in relation to smoking. This content should be addressed during undergraduate and postgraduate studies and in research projects that can better qualify the assistance provided to smokers.

A suggestion for future studies is to accompany CCT actions to evaluate the impact of these measures in relation to the number of smokers at the institution. Furthermore, we suggest studies that can contribute with actions and measures that target a tobacco-free environment.

It is concluded that the institutional policies of education, surveillance and penalty helped reduce smoking in the hospital environment. It is the responsibility of health professionals, especially of professional nurses, to assist, encourage and educate smokers and non-smokers about the importance of not smoking for the health of the population.

\section{DEFERENCES}

1. Ministério da Saúde (BR), Instituto Nacional do Câncer. Tabagismo passivo: a importância de uma legislação que gere ambientes 100\% livres de fumaça de tabaco: nota técnica. Rio de Janeiro; 2010.

2. World Health Organization. WHO framework convention on tobacco control [Internet]. Geneva; 2005 [cited in 2015 may. 28]. Available at: http://whqlibdoc. who.int/publications/2003/9241591013.pdf?ua=1

3. Presidência da República (BR). Lei no 12.546, de 15 de dezembro de 2011 [Internet]. Brasília (DF); 2011 [cited in 2013 oct. 6]. Available at: http://www. planalto.gov.br/ccivil_03/_at02011-2014/2011/lei//12546.htm

4. Andreis M, Elf J, Johns P, Carvalho A, Yuan J, Apelberg B. Air quality in bars of São Paulo/Brazil before and after the smoke-free law in indoor places. Rev Bras Cancerol. 2011:57(3):315-20.

5. Echer IC, Corrêa APA, Lucena AF, Ferreira SAL, Knorst MM. Prevalence of smoking among employees of a university hospital. Rev Latino-Am Enfermagem. 2011;19(1):179-86.

6. Albertasse L, Siqueira MM. Programa de controle do tabagismo do hospital universitário Cassiano Antônio de Moraes: perfil de usuários e funcionários. Rev Tempus Actas Saúde Col. 2013;7(2):85-96.

7. Iha LHC, Teixeira CC, Boaz SK, Echer IC. Actions of nurses to smoker patients hospitalized. Rev HCPA. 2012;32(4):427-35.

8. Barreto RB, Pincelli MP, Steinwandter R, Silva AP, Manes J, Steidle LJM. Smoking among patients hospitalized at a university hospital in the south of Brazil: preva- 
lence, degree of nicotine dependence, and motivational stage of change. J Bras Pneumol. 2012;38(1):72-80.

9. Sá-Silva JR, Almeida CD, Guindani JF. Pesquisa documental: pistas teóricas e metodológicas. Rev Bras Hist Ciênc Soc. 2009;1(1):1-15.

10. Ministério da Saúde (BR). Secretaria de Atenção à Saúde. Portaria SAS/MS n. ${ }^{4} 442$, de 13 de agosto de 2004 [Internet]. Braślia (DF); 2004 [cited in 2013 oct. 6]. Available at: ftp://ftp.cve.saude.sp.gov.br/doc_tec/cronicas/PortSAS442_ago04.pdf

11. Nunes SOV, Castro MRP, Lanssoni MMBS, Machado RCR. Ambiente livre de tabaCo. In: Nunes SOV, Castro MRP, organizadores. Tabagismo: abordagem, prevenção e tratamento. Londrina: Eduel; 2011. p. 57-64.

12. Agência Nacional de Vigilância Sanitária (BR). Resolução RDC n 46, de 28 de março de 2001 [Internet]. Braślia (DF); 2001 [cited in 2013 oct. 11]. Available at: http://portal.anvisa.gov.br/wps/wcm/connect/7ce59880 474586e39068d43fbc4c6735/Resolu\%C3\%A7\%C3\%A30+RDC +46_ Teores+e+embalagem_28Mar01.pdf?MOD=AJPERES

13. Laranjeira R, Ferreira MP. Como criar um hospital livre de cigarros. Rev. Ass. Med. Bras. 1997:43(2):169-72.

14. Radwan GN, Loffredo CA, Aziz R, Abdel-Aziz N, Labib N. Implementation, barriers and challenges of smoke-free policies in hospitals in Egypt. BMC Research Notes. 2012;5:568.
15. Carvalho AFS, Ferreira Júnior M, Silva ACCG, Oliveira AAP, Dias EC. Oportunidades de atuação do médico do trabalho no combate ao tabagismo. Rev Bras Med Trab. 2010; 8(1):16-22.

16. Lopes FM, Peuker AC, Bizarro L. Aplicação de um programa de cessação do tabagismo com rodoviários urbanos. Psicol Cienc Prof. 2013;33(2):490-9.

17. Silva ST, Campos MM, Faria FR, Cotta RMM. Combate ao tabagismo no Brasil: a importância estratégica das ações governamentais. Ciênc Saúde Coletiva. 2014;19(2):539-52.

18. Porto Alegre (BR). Lei complementar $n^{0}$ 728, de 8 de janeiro de 2014 [Internet]. Porto Alegre (RS); 2014 [cited in 2014 ago. 4]. Available at: http://lproweb.procempa.com.br/pmpa/prefpoa/dmlu/usu_ doc/728novocodigo.pdf

19. Corrêa APA, Echer IC. Profile and motivation for smoking cessation in surgical inpatients. Rev Gaúcha Enferm. 2015 mar;36(1):69-76.

20. Meier DAP, Vannuchi MTO, Secco IAO. Abandono do tratamento do tabagismo em programa de município do norte do Paraná. Rev Espaço Saúde 2012;13(1):35-44.

We would like to thank the Fundo de Incentivo à Pesquisa e Eventos of the Hospital de Clínicas de Porto Alegre.

\section{Author's address:}

Isabel Cristina Echer

Rua Doutor Veridiano de Farias, 55/603, Petrópolis

90670-010 Porto Alegre - RS

E-mail: isabelecher@gmail.com
Received: 17.12.2014

Approved: 14.07.2015 